\title{
Mycobacterium paratuberculosis and Crohn's disease
}

\author{
K Tanaka, M Wilks, P J Coates, M J G Farthing, J A Walker-Smith, S Tabaqchali
}

\begin{abstract}
The possible aetiological role of Mycobacterium paratuberculosis in Crohn's disease was investigated. The immunological response was studied using an enzyme-linked immunosorbent assay (ELISA), Western blotting, and immunocytochemistry. The antibody response to two protoplasmic antigen preparations of $M$ paratuberculosis in the sera of patients with inflammatory bowel disease was measured by ELISA. IgG and IgM antibodies to these antigens were measured in serum samples from 52 patients with Crohn's disease, 15 patients with ulcerative colitis, and 41 control patients without inflammatory bowel disease. Although there was wide variation in the concentrations of antibody detected, patients with Crohn's disease had concentrations that were not significantly different from those of the other two groups. In addition, mycobacterial antigens were separated by sodium dodecyl sulphate polyacrylamide gel electrophoresis and the immune response to each antigen was then examined separately and assayed for IgG and IgM in 10 patients from each of the three groups. An indirect peroxidase test was also used to detect $M$ paratuberculosis in sections of tissue from 18 patients with Crohn's disease and 10 with ulcerative colitis. The results were negative in all cases. This study does not support a role for -M paratuberculosis in Crohn's disease.
\end{abstract}

Although the aetiology of Crohn's disease remains unknown, a variety of bacteria have been implicated. ' Crohn's disease is a granulomatous ileitis histologically similar to that which occurs in tuberculosis, ${ }^{2-4}$ and this finding has prompted many investigators to attempt the culture of Mycobacteria from the tissue of patients with Crohn's disease. ${ }^{56}$ Granulomatous ileitis in ruminants, so called Johne's disease, is caused by $M$ paratuberculosis. Dalziel first drew attention to the histological similarity between Johne's disease in cattle and what was later to be called Crohn's disease in humans. ${ }^{2}$ Since the first report of this isolation of $M$ paratuberculosis from humans in $1984,{ }^{7}$ it has been isolated from seven patients in three different centres. The importance of these results and of serological studies, however, remains unclear. ${ }^{8}$ Thayer et al found that the antibody response to $M$ paratuberculosis in patients with Crohn's disease was significantly higher than in normal controls. ${ }^{9}$ In another study, however, no consistent IgG, IgM, or IgA antibody response was found in Crohn's disease patients. ${ }^{10}$ Because the antigen preparation that was used in the two studies was different, comparison is difficult. In a study of monkeys infected with $M$ paratuberculosis, those without clinical disease had antibodies to $M$ paratuberculosis, whereas those with disease did not." In an attempt to resolve this controversy we developed an ELISA to detect serum IgG and IgM concentrations to protoplasmic and surface antigen of $M$ paratuberculosis in patients with inflammatory bowel disease. In addition we have used an immunoblotting technique to identify mycobacterial antigens to which serum antibodies are directed and an immunocytochemical method to investigate the possible relation between $M$ paratuberculosis and Crohn's disease.

\section{Methods}

\section{SUBJECTS}

Sera were obtained from 52 patients with Crohn's disease (13 adults, mean age 32 years, range 17-55 years and 39 children, mean age $13 \cdot 2$ years, range $8-16$ years); 15 ulcerative colitis patients (eight adults, mean age 38 years, range $20-58$ years and seven children, mean age $12 \cdot 3$ years, range $6-16$ years); and 41 control patients ( 23 adults, mean age $37 \cdot 3$ years, range $17-5$ years and 18 children, mean age 10.8 years, range $6-16$ years).

ELISA FOR M PARATUBERCULOSIS ANTIBODY $M$ paratuberculosis protoplasmic antigen and surface antigen (Allied Laboratories, Ames, Iowa, USA) were used as antigens. Sera from infected cows with known high titres of antibody to $M$ paratuberculosis were purchased from Allied laboratories and used as positive controls.

\section{ANTISERA TO M PARATUBERCULOSIS ANTIGENS} WERE PREPARED IN RABBITS

Protoplasmic antigen or surface antigen $(2 \mathrm{mg} /$ $\mathrm{ml}$ in distilled water) was dispersed into an equal volume of Freund's incomplete adjuvant. Some $0.5 \mathrm{ml}$ of either antigen preparation was injected intramuscularly into the hind leg of a female New Zealand white rabbit of about $2.5 \mathrm{~kg}$. Immunisations were repeated and the rabbits were bled one month and three months after the first injection. Alkaline phosphatase conjugated goat anti-human IgG, IgM (Sigma, Dorset, UK) and rabbit anti-bovine IgG prepared as described by Voller $e t a l^{12}$ were used in our assay.

Initial calibration experiments were performed with positive bovine sera, hyperimmune sera, and 25 randomly selected serum samples. Each serum was double diluted over the range $1: 2$ to $1: 1024$ and $100 \mu \mathrm{l}$ volumes were used in the ELISA as described above.

Microtest III plates (Falcon, Becton Dickin- 
son) were coated with mycobacterial antigen at $0.04 \mathrm{mg} / \mathrm{ml}$ in carbonate/bicarbonate buffer $\mathrm{pH}$ 9.6. The plates were incubated overnight at $4^{\circ} \mathrm{C}$ and then washed three times with phosphate buffered saline (PBS) pH 7.4 containing 0.05\% (v/v) Tween 20 (PBS/T20). Bovine serum albumin $(1 \% \mathrm{w} / \mathrm{v})$ (Sigma, Dorset, UK) in PBS $\mathrm{pH} 7 \cdot 4$ (PBS/BSA) was added to the wells to reduce non-specific binding. The plates were incubated for two hours at room temperature, washed three times with PBS/T20, and stored at $-20^{\circ} \mathrm{C}$ until needed. One hundred $\mu \mathrm{l}$ of sera diluted 1:50 with PBS/BSA was added to the wells. After incubation overnight at $4^{\circ} \mathrm{C}$, the plates were washed three times with PBS/T20. Altogether $100 \mu \mathrm{l}$ of conjugate diluted $1: 1000$ for anti-human Ig and 1:400 for anti-bovine Ig respectively with $\mathrm{PBS} / \mathrm{BSA}$ was added to the wells. The plates were incubated for two hours at room temperature and washed three times with PBS/T20. A total of $100 \mu \mathrm{l} 1 \mathrm{mg} / \mathrm{ml}$ alkaline phosphatase substrate (Sigma 104) in substrate buffer $\mathrm{pH} 8.9$ consisting of $0 \cdot 2 \mathrm{M} \mathrm{NaCO}_{3}, 0 \cdot 2 \mathrm{M}$ $\mathrm{NaHCO}_{3}, 0.01 \mathrm{M} \mathrm{MgCl}_{2}$ was added and incubated for one hour at room temperature. The reaction was stopped with the addition of $100 \mu \mathrm{l}$ of $1 \mathrm{~N} \mathrm{NaOH}$ and the colour was read spectrophotometrically at $405 \mathrm{~nm}$ using a BioRad Model 2550 EIA reader (BioRad).

\section{IMMUNOBLOTTING}

Antigen preparations were dissolved in sodium dodecyl sulphate and electrophoresed in $10 \%$ polyacrylamide gels in a discontinuous buffer system at a constant current of $15 \mathrm{~mA}$. Proteins were transferred onto nitrocellulose paper and blotted by previously described methods.

\section{IMMUNOCYTOCHEMISTRY}

Immunostaining for $M$ paratuberculosis was performed by the indirect peroxidase method, using peroxidase conjugated swine anti-rabbit immunoglobulins (Dako Ltd, UK) and diaminobenzidine as chromogen. Endogenous peroxidase was inhibited by treatment with methanol/ hydrogen peroxide and non-specific binding of the primary antiserum was blocked by dilution in normal swine serum. Initially, sections were prepared from formalin fixed $M$ paratuberculosis which had been pelleted into low melting temperature agar and processed to paraffin wax. Subsequently, wax sections of tissue from patients with histologically diagnosed Crohn's disease $(n=18)$, ulcerative colitis $(n=10)$, and non-inflammatory bowel disease control subjects $(n=10)$ were similarly stained. Positive control sections (wax embedded $M$ paratuberculosis) and

IgG and IgM antibody response to $M$ paratuberculosis antigens in different patient populations measured by an ELISA

\begin{tabular}{|c|c|c|c|c|}
\hline \multirow[b]{3}{*}{ Patient group } & \multicolumn{4}{|c|}{ Mean $(S D)$ optical density $(460 \mathrm{~nm})$} \\
\hline & \multicolumn{2}{|c|}{ Surface antigen } & \multicolumn{2}{|c|}{ Protoplasmic antigen } \\
\hline & $I g G$ & $\operatorname{IgM}$ & $I g G$ & $I g M$ \\
\hline $\begin{array}{l}\text { Crohn's disease }(n=52) \\
\text { Ulcerative colitis }(n=15) \\
\text { Non-inflammatory bowel disease }(n=41)\end{array}$ & $\begin{array}{l}0.67(0.05) \\
0 \cdot 26(0 \cdot 20) \\
0.47(0.24)\end{array}$ & $\begin{array}{l}0.40(0.14) \\
0.45(0.46) \\
0.36(0.22)\end{array}$ & $\begin{array}{l}0.50(0.38) \\
0 \cdot 34(0 \cdot 18) \\
0.59(0.32)\end{array}$ & $\begin{array}{l}0 \cdot 19(0 \cdot 11) \\
0 \cdot 20(0 \cdot 17) \\
0 \cdot 25(0 \cdot 13)\end{array}$ \\
\hline
\end{tabular}

negative control sections (non-immune rabbit serum) were also performed. Sections were examined at high power magnification $(\times 40$ objective).

\section{Results}

\section{SERUM ANTIBODY RESPONSE}

The mean and range of optical density values obtained are shown in the Table. In each patient group there was a wide variation in the concentrations of antibody detected. Patients with Crohn's disease did not have significantly higher IgG or IgM antibody concentrations to either antigen preparation than the non-inflammatory bowel disease control patients or patients with ulcerative colitis. There was no correlation between the concentration of $M$ paratuberculosis antibody and the duration of disease illness in the Crohn's disease patients (results not shown).

\section{IMMUNOBLOTTING}

Seven major bands were detected whose apparent molecular weights varied from 17 to 50 kD. No specific band or band pattern was produced with either antigen, which distinguished the Crohn's disease patients from those with ulcerative colitis, or the noninflammatory bowel disease patients (results not shown). There was a strong IgG response against a $45 \mathrm{kD}$ antigen from the $M$ paratuberculosis protoplasmic antigen preparation in four of 10 Crohn's disease patients, and it was also weakly present in two other patients. However, a weak response to the same antigen was also given by four ulcerative colitis and one of the noninflammatory bowel disease patients. It is therefore unlikely to be of diagnostic use.

\section{DETECTION OF M PARATUBERCULOSIS IN TISSUE} SPECIMENS USING IMMUNOCYTOCHEMISTRY Immunocytochemical analysis of wax sections of formalin fixed $M$ paratuberculosis showed positive staining with each antiserum. No staining was observed when normal rabbit serum replaced the primary antisera, indicating the specificity of the method. The presence of $M$ paratuberculosis was not detected in any patient with Crohn's disease or ulcerative colitis.

\section{Discussion}

The serology of mycobacterial infections was recently described as a quagmire. ${ }^{8}$ Thayer et al reported increased concentrations of antibodies to $M$ paratuberculosis protoplasmic antigen in patients with Crohn's disease, compared with patients with ulcerative colitis or a healthy control group. In another study, however, SangNae Cho et $a l,,^{10}$ using a different antigen preparation, failed to find a consistent IgG, IgM, or IgA antibody response in patients with Crohn's disease. In our study, we have used the same protoplasmic antigen preparation as Thayer $e t a l^{9}$ together with a second surface antigen preparation. Although we were able to show IgG and IgM antibody activity in patients 
with Crohn's disease, antibody concentrations were similar in patients with ulcerative colitis and a control group without inflammatory bowel disease.

The antigen preparations used in the present study almost certainly contained a variety of different antigens, and therefore the ELISA measured the total antibody response to these antigens. It is possible that the antibody response to one of the antigenic components may be specific to Crohn's disease.

Immunoblotting, on the other hand, provides information on each antigenic component separately. No band(s) was detected which was specific to or more intense in patients with Crohn's disease. Although the $47 \mathrm{kD}$ antigen seemed dominant in four of 10 Crohn's disease patients, this antigen was also found in patients with ulcerative colitis indicating that it is of no diagnostic value.

Direct detection of $M$ paratuberculosis using an in situ immunoperoxidase technique has been reported in experimental infections of goats, ${ }^{13}$ but this has not been confirmed in studies of Crohn's disease. We failed to detect any $M$ paratuberculosis antigens in intestinal tissue sections from 18 patients with Crohn's disease.

The results of this study do not support an aetiological role for M paratuberculosis in Crohn's disease.

1 Kirsner JB, Shorter RG. Medical progress: recent developments in nonspecific inflammatory bowel disease. $N \mathrm{Englf}$ Med 1982; 48: 837-81.

2 Dalziel TK. Chronic intestinal enteritis. $\mathrm{Br} M e d \mathcal{F} 1913$; ii: 1068-70

3 Crohn BB, Ginzburg L, Oppenheimer GD. Regional ileitis: a pathologic and clinical entity. $\mathcal{F A M A}$ 1932; 99: 1323-9.

4 Moschcowitz E, Wilensky A. Non-specific granulomata of the intestine. Am F Med Sci 1923; 166: 48-66.

5 Burnham WR, Lennard-Jones JE. Mycobacteria as a possible cause of inflammatory bowel disease. Lancet 1978; ii: 693-6. 6 Patterson DSP, Allen WM. Chronic mycobacterial enteritis in ruminants as a model of Crohn's disease. Proc $R$ Soc Med 1972; 65: 998-1001.

7 Chiodini RJ, Van Kruiningen HJ, Thayer WR, Merkal RS, Coutu JA. Possible role of mycobacteria in inflammatory bowel disease. I: An unclassified Mycobacterium species isolated from patients with Crohn's disease. Dig Dis Sci 1984; 29: 1073-9.

8 Hampson SJ, McFadden JJ, Hermon-Taylor J. Mycobacteria and Crohn's disease. Gut 1988; 29: 1017-9.

9 Thayer WR, Coutu J, Chiodini RJ, Van Kruiningen HJ, Merkal RS. Possible role of mycobacteria in inflammatory bowel disease. II: Mycobacterial antibodies in Crohn's disease. Dig Dis Sci 1984; 29: 1080-5.

10 Cho Sang-Nae, Brennan PJ, Yoshimura HH, Korelitz BI, Graham DY. Mycobacterial aetiology of Crohn's disease, serologic study using common mycobacterial antigens and a species-specific glycolipid antigen from Mycobacterium paratuberculosis. Gut 1986; 27: 1353-6.

11 McClure HM, Chiodini RJ, Anderson DC, et al. Mycobacterium paratuberculosis infection in a colony of Stump-tail bacterium paratuberculosis infection in a colony of Stump-tail

12 Voller A, Bidwell D, Bartlett A. Enzyme immunoassays in diagnostic medicine. Theory and practice. Bull WHO 1976;
dict

13 Graham DY, Markesich DC, Estes MK, Yoshimura HH. Mycobacteria and inflammatory bowel disease: culture and DNA hybridization. Gastroenterology 1985; 90: 1436. 